\title{
Geopolitical rivalry of global powers and its implications in Nepal
}

\section{Geja Sharma Wagle}

\begin{abstract}
National unity and independence, territorial integrity, people's sovereignty and national security are the supreme priority for any sovereign and independent country across the world. The essence of national unity and security is the most important and highly sensitive issue for Nepal in account of its geopolitical sensitivities and geostrategic balance as Nepal is located between two giant nuclear countries and rising global powers - India and China. Analyzing the national interests and national security policy of all three countries - India, China and the US, it is open secret that they have direct strategic, defense and security interests in Nepal. They, therefore, have strategic rivalry to extend their political, diplomatic, economic, strategic, defense and security and cultural influence in Nepal because of its geopolitical importance and geostrategic sensitivity. The emerging triangular strategic rivalry may undermine Nepal's national interests and national security in the future as their rivalry gets intensified. It is a grave situation for Nepal which will have significant immediate as well as long-term implications. Nepal, therefore, should thoughtfully study to analyze the emerging global powers'defense, military, security and foreign policies and strategies and should protect and preserve Nepal's national interests and national security maintaining diplomatic and strategic balance among them.
\end{abstract}

Keywords: national security, strategic rivalry, geopolitical, geostrategic, IndoPacific strategy, belt and road initiatives, diplomatic balance

\section{Understanding security}

Security is 'essentially a contested concept' and it does not have a universally accepted definition (Galle, 1962, pp. 121-123). Security scholars agree that there is not even an agreement as to what 'security' means (Terriff, 2001, p. 1). The term 'security' has proved too complex and abstract, and there is much dispute about its meaning and definition. Writing as early as 1952 about the concept of security, a prominent security scholar Arnold Wolfer (1952) even argued that 'it may not have any precise meaning at all' (p. 149). Another noted security thinker Barry Buzan (1991) claims that the nature of security defies pursuit of agreed definition. It, therefore, is an underdeveloped and contested concept (pp. 3-5). The idea of security is defined through in terms of the state and the military-centric approach rather than people's perspective, so it has acquired a heavy military emphasis and domination.

Scholars like Hedley Bull, Bernard Brodie, Frank Trager, Frank Simonie, Hugh Macdonald, E. H. Carr and Hans Morgenthau have broadened its definition. Scholars, in particular, E. H. Carr and Hans Morgenthau, who were the proponents of realist school of thought, were dominant after the Second World War and defined security as a derivative 
of power. They define security in terms of protecting territorial integrity and core values of states against foreign intervention.

\section{Concept of national security}

In social sciences, national security is 'more controversial than the term 'security' without its specific authoritative definitions. In fact, national security is a 'recent notion and under-developed concept'. In line with Buzan's argument, Baldwin and Milner (1992) consider national security ambiguous, sensitive and value-laden terms in social science (p. 29). But national security is a quite important and sensitive issue that is directly inter-related to protecting national unity, territorial integrity and sovereignty of nation-states (Buzan, 1991, pp. 3-5). The theme of national security, therefore, is guided by a range of unique and traditional perceptions and realities, which are rooted in the history of an evolutionary process of nationhood. National security in its conceptual framework cannot be observed independently since it is closely related to the concept of national interest, national power and national stability (Sheeham, 2006, pp. 6-7). Howsoever, controversial, ambiguous and abstract it may be, it is a very important notion in social science because it studies the national unity, territorial integrity and political independence of a nation and the sovereignty and safety of its people.

Given the gravity and sensitivity of the issue that is related to sovereignty and independence of nation-states, security scholars had focused on state and military-centric approach. Defining from the traditional perspective of national security, some scholars who belong to the realist school of thought argue that the referent of security is the state and that it is the primary provider of security. If the state is secure, then those who live within it are secure (Bajpai, 2002, pp. 4-5). The national independence and territorial integrity are the most important requirements for a nation and these two values must be protected. If any state is attacked on these two values with violence, it must be responded with violence. There was a domination of the realist and the neo-realist schools of thought in the post-war fragile environment that have been advocating a state and military centric policy emphasizing on territorial integrity and military power.

Following the end of World War II, the concept of national security brought significant changes. In fact, the concept of national security developed following World War II when national security was emerging as the main challenge to the small and developing countries. However, security scholars have divergent thoughts regarding the changes. According to one of the prominent thinkers, David Baldwin (1995), there are three important elements for the change: 'First, it is the decline of the military power in the international politics. Second, it is the concept of international relations and national security which needs to be reexamined. Third, it is the national security, which appears to be viewed in broader terms' (pp. 117-18).

The implications of globalization and emerging multi-dimensional challenges of national security in the post-Cold War era have widened and broadened the definition of national security. There are many new dimensions, which have now become critical issues in security studies. Scholars have redefined security as a broader term that includes the citizens' security. Scholars belonging to Copenhagen school of thought contributed to broadening security studies. 
National security, therefore, moved 'beyond a narrow agenda, which focused on militarycentric concept' (Huysman, 1998, pp. 229-30).

The Human Development Report of 1994 prepared by Mahbub Ul Haq urged that the definition of security should be changed from the state-centric security to human security. According to the report, the concept of security should change in two ways: from an exclusive stress on territorial security to much greater stress on peoples' security, and from security through armaments to security through sustainable human development (UNDP, 1994). The threats to human security were synthesized in the report under seven broad categories - economic security, food security, health security, environmental security, personal security, community security and political security. Considering people's right to live, the United Nations developed an alternative concept that is human security. The concept of security has transformed into human security from statecentric approaches. In fact, national security is not only safety and security of the country and its citizens, but also is a universal process of safeguarding national values and interests against both internal and external threats that have the potential to undermine the security of the state and citizens.

\section{National security in the Nepali context}

National unity and independence, territorial integrity, people's sovereignty and national security are the most important priorities for any sovereign and independent country. The essence of national unity and security is the most important and highly sensitive issue for Nepal considering its geopolitical sensitivities and geostrategic balance as Nepal is located between two giant nuclear countries and rising global powers - India and China.
Moreover, Nepal shares an open border with its southern neighbor, India, and there are several border disputes between them. Nepal doesn't share open border with its northern neighbor, China, but has an equally important and sensitive relation. Nepal never became a colonial country, even during the adverse situations of the World War and the Cold War, and safeguarded its sovereignty and territorial integrity. But given its geostrategic importance and geopolitical sensitivity, national security is the most important and sensitive issue since Nepal's inception for centuries. The geostrategic dimensions and the relations with India and China are the crucial factors of national security of Nepal (Bhattarai, 2005, pp. 6-7).

Considering its geostrategic location, King Prithvi Narayan Shah, the founder of modern Nepal who laid the strong foundation for national unity and security, defined Nepal as a 'gourd between two rocks' and advocated a defensive strategy as the best way for Nepal to protect its territorial integrity and people's sovereignty in the DibyaUpades. He defined national security policy as a defensive policy that has been the guiding principle of security policy. It has been so long since King Shah defined the security policy and political, military and international contexts have significantly changed. Nepal has hitherto been following the very defensive policy as defined by Prithvi Narayan Shah. The Shah Dynasty and Rana regime followed the same theory as guiding principles for national security and followed state and military-centric policy regardless of changing political, social, economic and military context. In fact, they used the state and military-centric security policy to protect their regime rather than territorial integrity and sovereignty (Acharya, 2019, pp. 6-7). 
Following the establishment of democracy in 1950, Nepal emerged as a real nation-state and maintained good diplomatic relations with neighboring countries. Nepal became the member-state of the UN on 15 December 1955 and established diplomatic relations with the US, India, China, Germany, the USSR, Pakistan, Japan, France etc. Nepal's sovereignty, national unity and territorial integrity thus became more secure during the democratic era between 1950 and 1960 . At that time, King Mahendra abolished multiparty democracy and dissolved the people's elected government in 1960, took power, and imposed the partyless despotic Panchayat system in the name of nationalism (Kumar, 2003, pp. 321-323).

\section{National security policy of Nepal}

National security and people's security are so critical and challenging issues for Nepal. But unfortunately, Nepal did not have a written comprehensive national security policy until 2016. If Nepal had a well-defined, written and appropriate security policy, Nepal might have been able to protect its national interests and citizens' security. The successive governments and political parties did not pay heed to the national security policy even after the restoration of democracy in 1990 . But they merely beat the drum of ultranationalism and national independence for public consumption and political interests. In fact, in the absence of a written security policy, successive governments have been misusing the security agencies for their own political interests and convenience. Had the government promulgated a security policy clearly defining the roles and responsibilities of the security agencies, then there would have been fewer chances to misuse and abuse security agencies in the past.
Given the urgency of policy, the then government led by Madhav Kumar Nepal constituted a five-member Cabinet Committee under the leadership of then Defense Minister Bidhya Devi Bhandari in December 2009 to draft policy papers on national security policy, democratization of the army and strengthening and reforming law enforcement agencies under the Ministry of Home Affairs. The members of the committee were then Home Minister Bhim Rawal, Culture Minister Dr. MinendraRijal, Law Minister Prem Bahadur Singh and Minister without portfolio Laxman Lal Karna. The committee submitted its reports in August 2010.

Following the promulgation of the constitution in 2015, the government promulgated a written national security policy for the first time in the history of Nepal in 2016 (Ministry of Defense, 2016). Promulgating a new national security policy was seen as a positive step for ensuring national security and citizens' security but was also abstract and incomplete. Therefore, the first-ever security policy could not address the emerging internal and external security challenges of Nepal. The government did not consult with political parties, security agencies, security experts and concern stakeholders with regards to security policy, so the policy is dominated by the government's perspective. The new policy should have been redefined in line with the changed political and security contexts for three reasons. First, Nepal is in the process of transforming into a federal republic state from a feudal and unitary kingdom, and security threats for these two systems are fundamentally different. Second, the new constitution has defined human security as a guiding principle of national security, according to which, the role of the state is not only limited to defending its territory, 
but also to ensure freedom, human rights, peace and security of its citizens. Third, the internal and external threats to Nepal seem to be more complicated and challenging than before so that the new policy should have clearly identified both threats and outlined strategies to address them. But the policy did not address these serious issues.

Following the formulation of the government under the leadership of K P Oli in February 2018, the government promulgated a new national security policy in March 2019 taking into consideration the emerging internal and external security threats of Nepal (Ghimire, 2019). Analyzing both traditional and nontraditional security challenges, the new policy has identified foreign interference, open border, blockade, and border encroachment, cross border crime, terrorism and strategic rivalry of super powers and emerging global powers and others as the serious external threats of Nepal. But the government has not been made public the new policy, terming it a confidential and secret document. The security policy is not a secret and confidential document and it should make public like other policies of the government. Even the earlier security policy was made public by the government. If the previous one was made public, why not the new one? Unlike communist countries like China, North Korea, Cuba, every democratic country makes public their national security policy. Anybody can find on internet the national security strategies of countries like the US and the UK. Transparency and accountability ensuring the participation of people in law making process are the fundamental practice of democratic system so keeping any law confidential is against the democratic principles and spirit of the constitution. The government, therefore, should make the new security policy public without further delay under any pretext.

\section{Triangular geostrategic rivalry}

Given Nepal's geopolitical sensitivity and geostrategic importance, the super power - the US - and emerging global power and immediate neighbors - India and China have been giving a high priority to Nepal for a couple of decades to extend their political, diplomatic, strategic, security, economic and cultural influence in Nepal as per their own national interests. In fact, they have not only given a high priority, but also have increased their financial assistance, and development and military budget to Nepal. They, therefore, have been promulgating a number of policies and strategies focusing on Nepal and Asia, and have declared some financial support and development projects for Nepal for obvious reasons.

The US promulgated the much-media hyped strategy - Indo-Pacific Strategy (IPS) in June 2018 in order to extend its political, diplomatic, economic, defense and strategic influence in the entire Indo-Pacific region including Nepal in line with the American interests as stated in their national security and foreign policy. Following the promulgation of the IPS, it has been a much-debated issue in Nepal because the report has mentioned Nepal as an emerging defense partner for the first time. The IPS report (2019) mentions on Nepal -

The United States seeks to expand our defense relationship with Nepal, focused on HA/DR, peacekeeping operations, defense professionalization, ground force capacity, and counter-terrorism. Our growing defense partnership can be seen in the establishment of the U.S. Army 
Pacific-led Land Forces Talks in June 2018, our senior-most military dialogue with Nepal. This year has already seen several senior-level visits to Nepal by the USINDOPACOM Commander and Deputy Assistant Secretary of Defense for South and Southeast Asia to further advance our defense relationship. (p. 36)

The US have also promulgated a new law -Asia Reassurance Initiative Act (ARIA) - in 2019 focusing on the growing security challenges such as North Korea, the South China Sea, terrorism in Southeast Asia, human rights situation, and refugee issues of Tibet that will have direct security and strategic implications in Nepal. Likewise, the US has already agreed to provide $\$ 500$ million as grant as part of Millennium Challenge Corporation (MCC) for Nepal's infrastructure development as requested by the Government of Nepal. The muchdebated MCC compact was signed between Nepal and the US government in September 2017 in Washington DC. Likewise, the US government had officially invited Nepal's Foreign Minister Pradeep Kumar Gyawali in Washington in December 2018 and urged Nepal to play a central role in Indo-Pacific region that reflects the policy and priority of the US toward Nepal. The US has given such a high priority to Nepal for the first time in the history of Nepal-US diplomatic relations. Likewise, the US is the traditional supporter of the Nepali Army to make it well-trained, well-equipped, and professional; hence the US has been increasing its military budget to support the Nepali Army. The US had also significantly supported the Nepali Army during the decade-long armed insurgency in Nepal to control the then Maoist party's armed activities.
Not only has the US, China also significantly given a high priority to extend its influence in Nepal in line with the Chinese interests. President Xi Jinping visited Nepal this year and announced a significant policy outline during his visit. Nepal and China decided to upgrade its comprehensive partnership to a strategic partnership that depicts the strategy of China and priority of Nepal (Giri, 2019). In fact, Nepal has upgraded the much-hyped strategic partnership with China for the first time in the history of Nepal. According to the definition and objective of international relations, the strategic partnership is a broader and multi-dimensional cooperation in strategic, defense and security affairs in addition to social, economic and cultural dimensions. President Xi announced the substantial financial support to Nepal including rail and road connectivity as requested by Nepal. He had emphasized security and defense cooperation with Nepal during his visit so that Nepal and China signed on the Mutual Legal Assistance Treaty (MLAT) and agreed to sign an extradition treaty in the near future. President Xi had even highlighted the defense and security cooperation with Nepal in his article that was published in The Kathmandu Post on the eve of his visit.

In 2017, Nepal has already signed the Belt and Road Initiatives (BRI) - the highly ambitious and signature project of President $\mathrm{Xi}$ Jinping for infrastructure development and connectivity (Giri, 2017). According to the official document of BRI, it aims at enhancing policy coordination, connectivity, unimpeded trade, financial integration and people-topeople contact. The BRI is considered the mega project for infrastructure development and connectivity for and between Asia and Europe that has the potential to change the 
traditional geopolitical and geo-economics of the world. It, therefore, is both an opportunity and a challenge for Nepal. But Nepal needs to transform those challenges into opportunities and should implement the BRI projects in line with the national interest and national priority of Nepal to achieve its dream of development and prosperity maintaining good relations with India and the US.

Like the US, China has also promulgated some policies and strategies focusing on the Asia-Pacific region taking into consideration the US's growing strategic interests in the Indo-Pacific region. China analyses the increasing interests and influence of the US in the Asia-Pacific region as threats for China hence China wants to control or minimize the US's interests and influence. Taking into consideration the US's growing interests and influence, China promulgated a comprehensive security policy focusing particularly on the Asia-Pacific region for the first time in January 2017, 'China's policies on Asia Pacific security cooperation', which is similar to the IPS for the US (Ministry of Foreign Affairs, 2017). Likewise, China has also issued another important security document 'China's National Defense in the New Era' following the promulgation of the IPS (Hui, 2019). China has been establishing a close military and security cooperation with Nepal's security agencies - Nepali Army, Armed Police Force and Nepal Police - and has been increasing its military assistance to Nepal every year. Until few years ago, China was far behind with regards to military assistance to Nepal with India and the US, but today China has become the top donor of military assistance to Nepal.

India claims that it has the traditional sphere of influence in Nepal, therefore India has higher stake in Nepal compared to China and the US, given its centuries-old close, cordial and special political, diplomatic, economic, social, religious and cultural relations with Nepal. Nepal-India share an 1,800 km long open border and both countries have equally high security concerns and threats. India's concerns are not just limited to the strategic, defense and security affairs, but equally have important political, diplomatic, economic, social, religious and cultural interests in Nepal. India, therefore, wants to further extend its influence in Nepal and wants to control or minimize the growing influence of China and the US in Nepal. Given India's national interests and national security, Nepal is in the high priority of India and Prime Minister Narendra Modi himself has visited Nepal four times during his five-year tenure. Prime Minister Modi has been reiterating, time and again, that he will further deepen and widen the special and unique relations with Nepal for the best interests of two countries.

Prominent international relations thinker and Nobel Peace Prize laureate, Henry Kissinger (2014), has opined that India and China are the center of gravity of the emerging new multipolar world order, which will have significant implications in global politics (pp. 178-790). Likewise, noted geopolitical and strategic affairs scholar, Robert D Kaplan (2012), has highlighted heightening strategic and geopolitical gravity of Asia, and its implications in Nepal as Nepal is the epicenter of the emerging geopolitical rivalry of global power (pp. 252-53). Nepal, therefore, should understand the serious geostrategic and geopolitical realities of Nepal and should plan accordingly to ensure national unity, territorial integrity, people's sovereignty and independence of Nepal in the emerging world order. 
Analyzing the national interests and national security policy of all three countries - India, China and the US -it is obvious that they have direct strategic, defense and security interests in Nepal. They, therefore, have strategic rivalry to extend their influence in Nepal because of its geopolitical importance and geostrategic sensitivity. The emerging triangular strategic rivalry may undermine Nepal's national interests and national security in the future as their rivalry gets intensified. It is a critical issue for Nepal which will have significant immediate as well as longterm implications (Wagle, 2012, pp. 268-69). Nepal, therefore, should thoughtfully study and objectively analyze the emerging global power's strategic, defense, military, security and foreign policies and strategies and should protect and preserve Nepal's national interests and national security maintaining diplomatic and strategic balance in the given context.

\section{Conclusion}

Analyzing the evolving global and regional context, there is a geopolitical power play among the global powers. Against this backdrop of the triangular strategic rivalry, Nepal should maintain the diplomatic and strategic balance among the super powers and emerging global powers taking into consideration its national interests and national security. Otherwise, Nepal will turn into a geopolitical and geostrategic playground of the global powers undermining Nepal's national interests.

The national security policy of Nepal should be comprehensively reviewed and revised taking into consideration the emerging internal and external security threats. The government must make public the new policy that aims to safeguarding national unity, territorial integrity, people's sovereignty and national interests based on national consensus. The policy should embrace the fundamental principles of democracy, rule of law, human rights, and protect the long cherished identity, values and cultures of Nepal. The policy should also recognize the diversity and plurality of Nepali society. The policy should objectively assess the global context of peace, security and conflict in order to make it capable of dealing with emerging internal and external security threats.

The security agencies should be apolitical, professional and competent so that they can ensure the security of the nation and its people. They should be more accountable to the people, effective and impartial to perform their roles and responsibilities following the sound principles of good governance, the rule of law, human rights, transparency and accountability ensuring democratic control of security agencies. The security agencies should follow inclusive, people-friendly, rights-friendly and gender-friendly policies and should implement them accordingly. Democratic control of security agencies is a fundamental principle of democratic systems but security agencies should not be politicized on the pretext of democratic control as the government and political parties did in the past.

\section{References}

Acharya, M. R. (2019). Nepal worldview. Adroit Publishers. New Delhi.

Bajpai, K. (2002). Beyond comprehensive security: Human security. Comprehensive Security: Perspectives from India's Regions. New Delhi: New India Foundation.

Banerjee, D. (Ed.). (2000). Security studies in South Asia: Change and challenges. New Delhi: Manohar Publishers. 
Bhattarai, R. (2005). Geopolitics of Nepal and international responses to conflict transformation. Friends for Peace. Kathmandu.

Bienen, H. (Ed). (1992). Power, economics and security. Bulder co. West View Press.

Black, M. (1962). The importance of language. Eaglewood Cliffs, Princeton Hall.

Buzan, B. (1991). People, states and fear: An agenda for international security studies in the Post-Cold War era. Harvester Wheatsheaf.

Ghimire, B. (2019, March 29). Government's intent to keep security policy secret raises concerns. Kathmandu Post. Retrieved from https://kathmandupost. com/national/2019/03/29/governments-intentto-keep-security-policy-secret-raises-concerns

Giri,A.(2019,October 15). NepalandChina elevate bilateral ties to a 'strategic partnership' but no one's certain what that entails. Kathmandu Post. Retrieved from https://kathmandupost. $\mathrm{com} /$ national/2019/10/15/nepal-andchina-elevate-bilateral-ties-to-a-strategicpartnership-but-no-one-s-certain-what-thatentails

Giri, S. (May 14 2017). Nepal, China sign deal on OBOR. Kathmandu Post. Retrieved from https://kathmandupost. com/national/2017/05/12/nepal-china-signframework-deal-on-obor

Hui, L. (2019, July 24). China issues white paper on national defense in new era. Xinhue. Retrieved from http:/www.xinhuanet. com/english/2019-07/24/c_138253180.htm

Huysman, J. (1998). Revisit Copenhagen: or, on the creative development of a security studies agenda in Europe. European Journal of International Relations 14 (4).
Indo-Pacific Report (2019). Department of defense. Pentagon. Washington DC.

Kaplan, R. D. (2012). The revenge of geography. New York: Random House.

Kissinger, H. (2014). World order. Penguin Books.

Ministry of Foreign Affairs. (2017). China's policies on Asia-Pacific security co-operation. Retrieved from https://www.fmprc.gov. cn/mfa_eng/zxxx_662805/t1429771.shtml

Ministry of Defense. (2016). National security policy 2016. Retrieved from http://mod.gov. $\mathrm{np} / /$ public/files/23 1574029-National\%20 Security\%20Policy,\%202016.pdf

Sheeham, M. (2006). International security: An analytical survey. Viva Books. New Delhi.

Terriff, T. et al. (2001). Security studies today. Institute of Defense Studies and Analysis.

The Human Development Report. (1994). the United Nations. New York.

Wagle, G. S. \& Bhattarai, R., (Eds.). (2010). Emerging security challenges of Nepal. Nepal Institute for Policy Studies.

Wagle, G. S. et al. (Eds). (2013). Human security in Nepal: Concepts, issues and challenges. Nepal Institute for Policy Studies and South Asia Regional Coordination office of NCCR.

Wolfers, A. (1952). 'National security' as an ambiguous symbol. Political science quarterly, 67(4), 481-502. 